\title{
Early outcome after off-pump coronary artery bypass grafting: effect on mortality and stroke
}

\author{
Resultado inicial após revascularização miocárdica: efeito na mortalidade e no acidente cerebrovascular
}

Delawer REBER ${ }^{1}$, Marcus FRITZ², Alfred GERMING ${ }^{3}$, Peter MARKS ${ }^{4}$, Axel LACZKOVICS ${ }^{5}$

RBCCV 44205-945

\section{Abstract}

Objective: One of the major and devastating complications of the coronary artery bypass grafting (CABG) is the stroke. Avoiding cardiopulmonary bypass (CPB) may reduce this neurological complication. In the past years there was an increased interest in the off-pump coronary artery grafting (OPCAB). The benefit of this method of revascularization in term of stroke and mortality is controversially discussed.

Methods: A retrospective analysis of collected data from 252 patients were operated without cardiopulmonary bypass out of 1516 CABG procedures from January 2004 through May 2006. The mean age of the patient population was $70 \pm 11$ years, within a range of $27-88$ years. Forty-eight $(19 \%)$ patients were older than 80 years and there were $172(69 \%)$ males. Mean graft per patient was $1.78 \pm 0.79$. The internal mammary artery (IMA) graft was used in $95 \%$ of the patients. For $8(3.17 \%)$ patients this was the second procedure.
Results: Hospital mortality was $3.17 \%$; Mean EuroSCORE in these patients was 10.36 \pm 6.67 . No neurological complications occurred, six $(2.38 \%)$ patients had temporary psycho syndrome. Postoperative myocardial infarction occurred in $3(\mathbf{1 . 1 9 \% )}$ patients. Two patients required rethoracotomy as a result of bleeding. Thirty-eight (15\%) patients needed postoperative therapy for atrial fibrillation.

Conclusion: CABG with OPCAB technique has the benefit of low mortality and morbidity in terms of stroke. The advantages of this technique depends on the patient's general condition at the time of the operation, the sufficiency of pump function and coronary morphology, as well as on the surgeon's experience.

Descriptors: Myocardial revascularization. Coronary artery bypass/adverse effects. Cerebrovascular accident.

1. MD, staff cardiac surgeon.

2. MD, staff cardiac surgeon.

3. MD, cardiologist.

4. MD, junior staff.

5. MD, senior cardiothoracic surgeon.

Work done at Department of Cardiothoracic Surgery, Bergmannsheil, Ruhr University Hospital, Bochum, Germany.

Correspondence address:

Dr. Delawer Reber

Ruhr University Hospital - Buerkle-de-la-Camp-Platz-1 44789 Bochum, Germany. Tel: 49(0)234 3023607. Fax: 49(0)234 3026010.

E-mail: delawer.reber@rub.de

Article received on December $1^{\text {st }}, 2007$ Article accepted on February 25 $5^{\text {th }}, 2008$ 


\section{Resumo}

Objetivo: Uma das principais e devastadoras complicações da revascularização do miocárdio é o acidente cerebrovascular. Evitar a circulação extracorpórea (CEC) pode reduzir essa complicação neurológica. No passado, houve um interesse crescente na cirurgia de revascularização do miocárdio sem circulação extracorpórea. $O$ benefício deste método de revascularização com relação ao acidente cerebrovascular e à mortalidade ainda é discutido de forma controversa.

Métodos: Uma análise retrospectiva dos dados coletados de 1.516 pacientes submetidos à cirurgia de revascularização do miocárdio, de janeiro de 2004 a maio de 2006, dos quais 252 pacientes que foram operados sem circulação extracorpórea. A média de idade da população da amostra foi de $70 \pm 11$ anos, variando de 27 a 88 anos. Quarenta e oito pacientes $(19 \%)$ tinham mais de 80 anos e 172 pacientes $(69 \%)$ eram homens. O número médio de transplante por paciente foi de $1,78 \pm 0,79$. A artéria torácica interna (ATI) foi usada em $95 \%$ dos

\section{INTRODUCTION}

The history of OPCAB (Off-Pump Coronary Artery Bypass Grafting) surgery goes back to the 1950s, where endarterectomy with saphenous vein graft was widely used [1]. In 1952, animal experiments were done with the use of the internal mammary artery to the coronary arteries [2]. Similar results could be achieved by using a saphenous vein graft to the left anterior descending artery (LAD) done by Garret, in 1964 [3]. In the same year, left internal mammary artery (LIMA) to LAD was performed by Kolesov [4]. All these operations were performed by using the off-pump technique.

At the end of the 1960s, CABG surgery with the use of extracorporeal circulation in the arrested heart was widely used, and the OPCAB surgery was more or less abandoned after the implementation of the modern cardiopulmonary bypass.

In the 1970s, Favaloro [5] reported good results with OPCAB surgery; nevertheless, CABG with cardiopulmonary bypass (CPB) remained the main technique for coronary revascularization until the end of the eighties. By then it was known that the CPB would induce whole-body inflammatory response, which causes increased mortality and morbidity [6] in addition to the trauma effect of the cannulations and its subsequent thromboembolic mechanism. However, the neurological trauma may reach 2.7\%-3.1\% [7].

Further development of the technologies and modification of OPCAB in the early and mid 1990s, as well as surgical and anaesthesiological improvements once again led to increased interest in that technique [8].

The purpose of this study was to show and analyse our experience in CABG with OPCAB-technique with regard to neurological trauma (stroke) and mortality. pacientes, enquanto que para oito pacientes a ATI foi o segunda procedimento.

Resultados: A mortalidade hospitalar foi de 3,17\%; o EuroScore médio nesses pacientes foi de 10,36 $\pm 6,67$. Não ocorreram complicações neurológicas, porém, seis pacientes $(2,38 \%)$ tiveram psicossíndrome temporária. Infarto do miocárdio ocorreu em três pacientes $(1,19 \%)$ após a cirurgia. Dois pacientes precisaram fazer uma nova toracotomia por motivo de sangramento e 38 (15\%) de tratamento para fibrilação atrial após a cirurgia.

Conclusão: A cirurgia de revascularização do miocárdio sem circulação extracorpórea apresenta o benefício da baixa mortalidade e morbidade com relação ao acidente cerebrovascular. As vantagens dessa técnica dependem da condição geral do paciente na época da cirurgia, da suficiência da função da bomba e da morfologia coronária, bem como da experiência do cirurgião.

Descritores: Revascularização miocárdica. Ponte de artéria coronária/efeitos adversos. Acidente cerebrovascular.

\section{METHODS}

From January 2004 to May 2006, 252 patients were operated without cardiopulmonary bypass. The preoperative patient's characteristics are listed in Table 1.

Table 1. Preoperative patients’ characteristics.

\begin{tabular}{|c|c|c|}
\hline & & Mean \% \\
\hline Age (years) & $27-88$ & $70 \pm 11$ \\
\hline$>80$ years & 48 & 19 \\
\hline Male & 172 & 69 \\
\hline Female & 80 & 31 \\
\hline One vessel disease & 49 & 19.4 \\
\hline Two vessel disease & 71 & 28.2 \\
\hline Three vessel disease & 132 & 52.4 \\
\hline \multicolumn{3}{|l|}{ Ejection fraction \% } \\
\hline$>50$ & 191 & 76 \\
\hline Between 30-50 & 53 & 21 \\
\hline$<30$ & 8 & 3 \\
\hline Preoperative PTCA & 69 & 27 \\
\hline EuroSCORE (all patients) & & $5.1 \pm 3.6$ \\
\hline Main stem stenosis & 71 & 28 \\
\hline \multicolumn{3}{|l|}{ Myocardial infarction } \\
\hline$<48 \mathrm{~h}$ & 8 & 3 \\
\hline$<90$ days & 35 & 14 \\
\hline Diabetes & 60 & 24 \\
\hline \multicolumn{3}{|l|}{ Obesity } \\
\hline Prior bypass surgery & 8 & 3 \\
\hline Emergency or ultima ratio & 14 & 6 \\
\hline Hypercholesterolemia & 212 & 84 \\
\hline Hypertension & 229 & 91 \\
\hline Prior TIA or stroke & 27 & 10.7 \\
\hline
\end{tabular}




\section{Operative management and surgical technique}

Informed consent was obtained from all patients subsequently to being properly briefed about the procedure. In order to plan the grafts all angiographies were reviewed in the early morning.

Prior to the operation all patients received their preoperative medication such as nitrates, ß-blockers, antihypertensive, ACE inhibitors and diuretics up to the time of the operation. A perfusionist was always present in the operating theatre.

Central venous catheter was inserted and electrocardiography as well as arterial pressure control was performed.

After median sternotomy, harvesting of the LIMA and saphenous vein was performed, Heparin at a dose of 300 $\mathrm{IU} / \mathrm{kg}$ was administered, and activated clotting time (ACT) was maintained at a level of $>400 \mathrm{~s}$. At the end of proximal anastomoses protamine was given at a dose rate of $1: 1$ and the effect was determined by ACT.

During the operation, aprotinin was infused with $(1000$, $000 \mathrm{KIU})$. To keep the patient's temperature above $35^{\circ} \mathrm{C}$ the patient was placed on a warming mat throughout the operation.

A deep pericardial traction suture (LIMA-Stitch) was placed between the inferior vena cava and the left inferior pulmonary vein to facilitate the elevation of the apex of the heart and the exposure of the posterior wall of the myocardium. Stabilization of the coronary arteries was accomplished by using two different commercially available stabilization systems: Octopus ${ }^{\mathrm{TM}}$ (Medtronic, Minneapolis, $\mathrm{MN}$ ), and Estech (OPVAC ${ }^{\circledR}$ SYNERGY ${ }^{\mathrm{TM}}$ ). At the surgeon's preference intraluminal coronary shunts were inserted whenever possible or a silicon loop was used to keep the operating field bloodless. Atrial pacing was established in case of bradycardia. Distal anastomoses were performed using a continuous running 7-0 monofilament suture for the venous graft and 8-0 for the arterial grafts. Proximal anastomoses were constructed after aortic side clamping using a 6-0 running suture. In 17 patients the proximal anastomoses was reconstructed with the PAS-PORT system device (Cardica ${ }^{\mathrm{TM}}$ Inc, CA, USA).

According to the principle of functional revascularization, the anterior wall of the myocardium was bypassed first with LIMA to LAD, then right coronary artery vessel or its branches, and finally the obtuse marginal branches.

\section{Definition of outcome parameters, data collection}

Myocardial infarction (MI) was defined as the occurrence of a new Q-wave on the ECG and /or an increase of creatine kinase-MB fraction of more than $10 \%$ of the creatine kinase. Neurological injury was defined as postoperative stroke. Transient psychsyndrom was defined as minor behavioural complication.
All data was entered into a database (Microsoft) and was retrospectively analyzed. Data is presented as mean \pm SD.

\section{RESULTS}

The number of grafts varied from 1-4, an average of 1.78 \pm 0.79 grafts per patient were done. LIMA was used in $95 \%$ of patients. The mean operation time was $132 \pm 37 \mathrm{~min}$. One hundred seven (42\%) patients underwent one bypass graft, 99 (39\%) patients received two grafts, 40 (16\%) had three grafts and six (2\%) had four grafts (Table 2).

Table 2. Intraoperative data.

\begin{tabular}{lc}
\hline Single bypass & $107(42 \%)$ \\
Double bypass & $99(39 \%)$ \\
Triple bypass & $40(16 \%)$ \\
Quadruple bypass & $6(2 \%)$ \\
Number of peripheral anastomoses & $1.78 \pm 0.79$ \\
Use of ITA graft & $95 \%$ \\
Mean operation time (min.) & $132 \pm 37$ \\
\hline
\end{tabular}

\section{Hospital mortality and morbidity}

Hospital mortality was in eight (3.1) patients. The primary causes of death was myocardial infarction in one patient, sudden death in one patient, multiorgan failure in three patients, two patients died as result of sepsis, and one patient died because of pneumonia. The average EuroSCORE of the deceased patients was 10.36 \pm 6.6 .

No stroke was observed, however six (2.38\%) patients suffered transient psychsyndrom. Three (1.19\%) patients had postoperative myocardial infarction and there were significant arrhythmias (atrial fibrillation) in 38 (15\%) patients. Rethoracotomy as a result of bleeding in two $(0.8 \%)$ patients, the mean use of blood units was $1.86 \pm 3.6$, there were four (1.59\%) deep wound infections requiring surgical intervention (Table 3).

Table 3. Postoperative data.

\begin{tabular}{lc}
\hline Hospital mortality & $8(3.1 \%)$ \\
Perioperative myocardial infarction & $3(1.19 \%)$ \\
Atrial fibrillation & $38(15 \%)$ \\
Transient psycho syndrome & $6(2.38 \%)$ \\
Use of blood units & $1.86 \pm 3.60$ \\
Rethoracotomy as a result of bleeding & $2(0.8 \%)$ \\
Deep sternal infection & $4(1.59 \%)$ \\
\hline
\end{tabular}




\section{DISCUSSION}

Controversy still exists concerning the clinical outcome of OPCAB patients with regard to morbidity and mortality in elderly patients with multiple comorbidities and whether or not OPCAB is superior to conventional CABG.

Surgical techniques are constantly in development, such as establishing the OPCAB procedure and developing innovative techniques such as stabilizers, intracoronary shunts to induce bloodless field, better intraoperative coordination with anaesthesiologists and better monitoring. All these resulted in excellent performance of anastomosis in multivessel disease without CPB [9].

The average age of our patient population was 70 years, 48 (19\%) were $>80$ years old. We evaluated our risk prediction by using the European System for Cardiac Operative Risk Evaluation (EuroSCORE) [10]. The average EuroSCORE in all of our patients was 5.1 \pm 3.8 . We registered a hospital mortality of $3.1 \%$.

CABG on the beating heart in elderly patients is controversially debated in the literature. Some studies concluded to have lower morbidity and mortality [11]. In an earlier study done by our group as well as in other studies no significant difference in terms of mortality were found [12,13].

In this study our postoperative results with regard to perioperative morbidity was relatively low in terms of myocardial infarction (1.19\%), blood transfusions (1.8\%), rethoracotomy as a result of bleeding (0.8\%) and deep sternal wound infection (1.59\%). Our results are somewhat similar to those found in the literature [14,15].

In a multi-centre study performed by the group of $\mathrm{M}$. Mack [16] it was determined that there is a 73\% higher mortality rate in females compared to males. We have similar result in this study, Six out of eight of our deceased patients were females.

We are of the same opinion as Kilo et al. [17] whether or not the complete revascularization in elderly patients is justified. They found that in elderly patients the incomplete revascularization OPCAB may yield better operative results than complete revascularization on-pump. Perioperative complications were more frequent and midterm survival was worse in the on-pump patient group.

One of the major and devastating complications after CABG surgery is stroke; it results in disability of the patient and prolonged hospital stay and costs.

In our study there was a $0 \%$ stroke rate. Almost all authors in the literature will agree that patients receiving the OPCAB procedure were less likely to have a stroke rate in comparison with the conventional CABG, and the stroke rate remains low even in high-risk patients $[18,19]$.

One of the most predictors of stroke after CABG is manipulation of ascending thoracic aorta which may be atherosclerotic which leads to release atheromatose and calcific debris which can embolize to the brain [20].

OPCAB surgery may avoid these complications because it has a potential to reduce the need for aortic manipulation and it is associated with reduced level of S-100 protein as compared to conventional CABG [21].

It is clear that "no touch aorta" operative technique in severely atherosclerotic cases results in fewer neurological complications. One hundred and seven of our patients have no touch aorta.

Other postulations for neurological deficits are embolization of fat particles, air bubbles and fibroelastom tissues [22].

Zamvar et al. [23], who performed a randomized controlled trial, found less neurological adverse events in the OPCAB group than with the conventional CABG.

Some are doing routine intraoperative transesophageal echocardiography which have showed to be safe and accurate to evaluate the extension of the aortic calcification. Sharony et al. [24] showed significant reduction of stroke in the group of OPCAB compared to conventional CABG.

OPCAB also shows reduced coagulation impairment and similarly other studies reported reduced inflammatory response after off-pump surgery [25].

In the past years, we have learned to find an appropriate surgical strategy and to properly select patients who may possibly benefit from OPCAB.

Our selection criteria of patients for OPCAB is diseased aorta ascendens (no touch aorta or proximal anastomosis device with PAS-PORT system), advanced age $>75$ years and patients with sever comorbidity, particularly in patients with preoperative neurological deficits.

A plane X-ray should be done preoperatively in which sometimes you can determine the extension of the atheromatose ascending aorta.

However the choice of appropriate surgical strategy depends on patient's clinical status and surgeon's experience.

A screening carotid ultrasonography will be performed in all patients who undergo CABG in our department. According to the grade of stenosis and neurological symptoms we will achieve carotid endarterectomy first and after a week the CABG operation in OPCAB technique, this has been done in two of our patients.

We believe that OPCAB in experienced hands is beneficial and yields better results, particularly in elderly patients.

It is a limitation of this study that it is retrospective and does not refer to patency with randomized angiography and midterm outcome. A randomized comparative study with conventional CABG is needed. 


\section{CONCLUSION}

CABG with OPCAB technique demonstrates low mortality and morbidity in terms of Stroke. The advantages of this technique depends on the patient's general condition at the time of the operation, the sufficiency of pump function and coronary morphology, as well as on the surgeon's experience.

\section{REFERENCES}

1. Westaby S, Benetti FJ. Less invasive coronary surgery: consensus from the Oxford meeting. Ann Thorac Surg. 1996;62(3):924-31.

2. Demikhov VP. Experimental transplantation of vital organs (authorized translation from Russian by Basil Haigh). In: Consultants Bureau Enterprises. New York, NY; 1962. p.220-7.

3. Westaby S. Landmarks in cardiac surgery. Oxford:Isis Medical Media;1997.

4. Spencer FC, Galloway AC, Colvin SB. Surgical management of coronary artery disease. In: Sabiston Jr DC, Spencer FC, eds. Surgery of the chest. $6^{\text {th }}$ ed. Philadelphia;Saunders; 1995 . p.1884-5.

5. Favaloro RG, Effler DB, Groves LK, Sheldon WC, Sones Jr FM. Direct myocardial revascularization by saphenous vein graft. Present operative technique and indications. Ann Thorac Surg. 1970;10(2):97-111.

6. Kirklin JK, Westaby S, Blackstone EH, Kirklin JW, Chenoweth $\mathrm{DE}$, Pacifico AD. Complements and the damaging effects of cardiopulmonary bypass. J Thorac Cardiovasc Surg. 1983:86(6):845-57.

7. Engelman DT, Cohn LH, Rizzo RJ. Incidence and predictors of tias and strokes following coronary artery bypass grafting: report and collective review. Heart Surg Forum. 1999;2(3):242-5.

8. Pfister AJ, Zaki MS, Garcia JM, Mispireta LA, Corso PJ, Qazi AG, et al. Coronary artery bypass without cardiopulmonary bypass. Ann Thorac Surg. 1992;54(6):1085-91.

9. Shennib H, Lee AG, Akin J. Safe and effective method of stabilization for coronary artery bypass grafting on beating heart. Ann Thorac Surg. 1997;63(4):998-92.
10. Nashef SA, Roques F, Michel P, Gauducheau E, Lemeshow S, Salamon R. European system for cardiac operative risk evaluation (EuroSCORE). Eur J Cardiothorac Surg. 1999;16(1):9-13.

11. Magee MJ, Coombs LP, Peterson ED, Mack MJ. Patient selection and current practice strategy for off-pump coronary artery bypass surgery. Circulation. 2003;108(Suppl 1):II9-14.

12. Fritz MK, Wiebalck A, Buchwald D, Reber D, Klak K, Laczkovics AM. Off-pump versus on-pump coronary artery bypass surgery. Comparison of 270 case-matched elderly patients. Z Kardiol. 2004;93(8):612-7.

13. Racz MJ, Hannan EL, Isom OW, Subramanian VA, Jones $\mathrm{RH}$, Gold JP, et al. A comparison of short-and long-term outcomes after off-pump and on-pump coronary artery bypass graft surgery with sternotomy. J Am Coll Cardiol. 2004;43(4):557-64.

14. Cheng DC, Bainbridge D, Martin JE, Novick RJ. Does offpump coronary artery bypass reduce mortality, morbidity, and resource utilization when compared with conventional coronary artery bypass? A meta-analysis of randomized trials. Evidence-Based Perioperative Clinical Outcomes Research Group. Anesthesiology. 2005;102(1):188-203.

15. Ascione R, Reeves BC, Rees K, Angelini GD. Effectiveness of coronary artery bypass grafting with or without cardiopulmonary bypass in overweight patients. Circulation. 2002;106(14):1764-70.

16. Mack MJ, Brown P, Houser F, Katz M, Kugelmass A, Simon A, et al. On-pump versus off-pump coronary artery bypass surgery in a matched sample of women: a comparison of outcomes. Circulation. 2004;110(11 Suppl 1):II1-6.

17. Kilo J, Baumer H, Czerny M, Hiesmayr MJ, Ploner M, Wolner E, et al. Target vessel revascularization without cardiopulmonary bypass in elderly high-risk patients. Ann Thorac Surg. 2001;71(2):537-42.

18. Calafiore AM, Di Mauro M, Contini M, Di Giammarco G, Pano M, Vitolla G, et al. Myocardial revascularization with and without cardiopulmonary bypass in multivessel disease: impact of the strategy on early outcome. Ann Thorac Surg. 2001;72(2):456-62.

19. Demaria RG, Carrier M, Fortier S, Martineau R, Fortier A, Cartier R, et al. Reduced mortality and strokes with off-pump coronary bypass grafting surgery in octogenarians. Circulation. 2002;106(12 Suppl 1):I5-10.

20. Kapetanakis EI, Stamou SC, Dullum MK, Hill PC, Haile E, Boyce SW, et al. The impact of aortic manipulation on neurologic outcomes after coronary artery bypass surgery: a risk-adjusted study. Ann Thorac Surg. 2004;78(5):1564-71. 
21. Diegeler A, Hirsch R, Schneider F, Schilling LO, Falk V, Rauch $\mathrm{T}$, et al. Neuromonitoring and neurocognitive outcome in offpump versus conventional coronary bypass operation. Ann Thorac Surg. 2000;69(4):1162-6.

22. Babikian VL, Caplan LR. Brain embolism is a dynamic process with variable characteristics. Neurology. 2000;54(4):797-801.

23. Zamvar V, Williams D, Hall J, Payne N, Cann C, Young K, et al. Assessment of neurocognitive impairment after off-pump and on-pump techniques for coronary artery bypass graft surgery: prospective randomised controlled trial. BMJ. 2002;325(7375):1268.

24. Sharony R, Bizekis CS, Kanchuger M, Galloway C, Saunders PC, Applebaum R, et al. Off-pump coronary artery bypass grafting reduces mortality and stroke in patiets with atheromatous aortas: a case control study. Circulation. 2003;108(Suppl 1): II15-20.

25. Angelini GD, Taylor FC, Reeves BC, Ascione R. Early and midterm outcome after off-pump and on-pump surgery in Beating Heart Against Cardioplegic Arrest Studies (BHACAS 1 and 2): a pooled analysis of two randomised controlled trials. Lancet. 2002;359(9313):1194-9. 